\title{
Impact of absorptive capacity and dominant logic on innovation performance of public sector organizations in Hefei (Anhui Province), China
}

\author{
Farhan Khan $^{a^{*}, Z^{2}}$ Zhang Xuehe ${ }^{a}$, Fouzia Atlas ${ }^{\text {a }}$, Kashif Ullah Khan ${ }^{a}$, Adnan Pitafia and Muham- \\ mad Usman Saleem ${ }^{a}$
}

${ }^{a}$ University of Science and Technology of China, Hefei Anhui Province, China

\begin{tabular}{l}
\hline C H R O N I C L E \\
\hline Article history: \\
Received: October 1, 2016 \\
Received in revised format: No- \\
vember 16, 2016 \\
Accepted: March 16, 2017 \\
Available online: \\
March 16, 2017 \\
\hline Keywords: \\
Innovation performance \\
Public organization \\
Dominant logic
\end{tabular}
A B S T R A C T
Public organization's performance depends on multiple aspects in which there are different political and public actors involved. In this study, we discuss the innovation performance of public organizations' in Hefei (Anhui province), China. Our targeted group for this study were public sector employees at different levels within the organizations being considered. We checked the effect of absorptive capacity (ACAP), and dominant logic on public organization's innovation performance. We found that absorptive capacity and dominant logic had a positive relationship with firms' performance. Furthermore, these predictors were not only improving firm's performance, but also bring innovation into the public organizations.

\section{Introduction}

In a tumultuous and dynamic environment, knowledge creates significant resources and develops competitive advantage (Teece et al., 1997). In the last 20 years absorptive capacity (ACAP) has become one of the most important constructs, since external knowledge resources have become significant. During the management of the external knowledge ACAP helps the firms develop value and achieve competitive advantage (César Camisón, 2010). In this study our focus is on the effect of ACAP and dominant logic (Chandler \& Hamks, 1994) over public service organization's performance. The objective was to combine these two intangible resources in one model to check the public sector organization's performance. In previous research absorptive capacity and dominant logic were examined in the area of private sector firms. After the work of (Cohen \& Levinthal, 1989) regarding absorptive capacity, several academic and empirical studies have examined organizational capability to absorb knowledge. The concept of ACAP provides enough flexibility that it can be applied to various units of analysis,

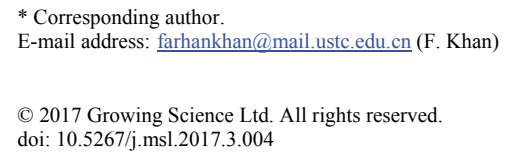


and research fields such as industry related organizations, learning in organizations, strategic management and innovation management (Zahra, 2002). DL deals with the organizations' resource allocation decisions and conceptualization. That can be in technology, development of products, distribution, advertising, or in human resources (Prahald, 2004). Moreover, DL is the DNA of the Organization (Prahald, 2004, p.172) and a key variable that is exceptional, valuable, and hard to emulate resources of the organization (Amit, 1993). Whereas, the idea of DL is academically appealing, and still empirical support is weak to date (Oblój \& Pratt, 2005). Various terms are used for dominant logic in prior research, (Prahalad \& Bettis, 1986), counting "mind-sets" (Nadkarni, 2007), "interconnected choices" (Siggielkov, 2002), and "strategic frames" (Huff, 1982). Each of the terms deal with the managers' ability to distinguish and adapt their firms according to the environment (Obloj, 2010). In this study, we focus on the knowledge and its positive effects on the public organizations' innovation performance. Our study is supported by absorptive capacity and dominant logic. According to Prahalad and Bettis (1986, p.491) Dominant logic is defined as an administrative tool to get future goals to make decisions about business at different levels of organizations processes. Strong test for dominant logic and its relevance are offered by transition economies. Specially, those economies, which are converted from socialist economic system to market economy for example China. In such kind of environment there are more tests offered to dominant logic to test its potential, and importance as intangible resource in limited resource environment (Kolvereid \& Oblój, 1994; Bruton, 2008; Meyer \& Peng, 2005). Whereas, latest research argues that for competitive advantage intangible resource are the principle resource (Amit, 2003). By definition it is hard to transfer the intangible resources (Szulanski, 2000), more difficult to replicate than tangible/physical resources (Dierickx, 1989), as well as it is harder to deal with market with these resources (Barney, 1986a). Other than the significance of the intangible resources, there has been a little empirical study and their relationship, the resulting capabilities, and the performance of the firms (Carmeli, 2004; Makadok, 2001; Newbert, 2007). This study is based on the following questions:

- How absorptive capacity affects the public organization's innovation performance?

- What role does dominant logic play in order to improve the public organization's innovation performance?

The structure of this paper is based on four parts. First part presents the hypothesis and literature review on absorptive capacity, dominant logic and their significance with public organizations' performance. Second part, presents the research method employed for analysis in this study. Third, represents the results and the relationship between variables, by using multiple regression modeling. And the last part is discussion and conclusion.

\section{Hypotheses and Literature Review}

\subsection{Absorptive capacity and public organizations' innovation performance}

Prior knowledge and new knowledge may be related to extend the case that knowledge itself as a learning skill. Across the bodies of knowledge there may be transfer of learning skills that are organized and stated in similar ways. On some subsequent learning tasks effect, experience routine on one learning task may impact as well as develop performance (Ellis, 1965). This kind of progressive improvement in the learning tasks' performance is due to the transfer of knowledge that could also be called as "learning to learn" (Ellis, 1965; Estes, 1970). Estes (1970: 16), mentioned the expression "learning to learn" is a misnomer according to which previous experience would not develop recital. Since an individual must be acquainted with learning in a better way, whereas, an individual may have gathered more prior knowledge for attaining a given level of performance he or she needs to learn less (Cohen, 1990). In a variety of tasks succeeding learning tasks can be observed such as, in the case of problemsolving skills. From prior knowledge problem-solving techniques have been composed. This allows individuals to obtain capabilities that are related to problem-solving capabilities. Pirolli and Anderson 
(1985) worked on computer related programming skills and development and found that approximately every student developed new program by analogy-to-example programs. The accomplishment was measured by their understanding of these cases and why they worked in reality. Developing absorptive capacity in the sense of knowledge in general, problem-solving and leaning skills is inadequate to describe and pinpoint the relevant prior knowledge (Cohen, 1990). Lin et al. (2002) mentioned that it is impossible for a firm to integrate and apply the external knowledge without absorptive capacity. Moreover, they mentioned that during transfer (in technology transfer, for example) critical factors needed for absorptive capacity and found realistic relationship between absorptive capacity and factors related to the diffusion channels for external technology, organizational interactions, and R\&D resources. Gupta and Govindarajan (2002) mentioned that for effective knowledge management it is important to build an environment within which individuals work during critical situations that are also challenging in there nature. Two different approaches of knowledge management have been mentioned by (Grundstein, 2007); first, technological approach which deals with the demand solution that is based on the technology. Second, approach deals with the management that is more "people-focused" (Wiig, 2003 ); in which knowledge is used as a resource to implement strategic vision of the organization. Hogarth (2001) mentioned the capabilities of the knowledge management that contributes to the organizational effectiveness and developed operations of the organizations by generating value. The contributions may expand ability to innovate, improve coordination and reduce redundancy of information/knowledge. Ho (2008) argued that joining knowledge management and human resource management initiatives would help to improve organization's performance. Knowledge management becomes one of the most important factors for these organizations as they identify that competitive advantage centers on effective management of their vast and diverse knowledge assets (Davenport, 1998; Wiig, 2003). Knowledge management goals deal with the development of knowledge assets of the organization to get superior knowledge practices, develop organizational learning behaviors, and improve decision making process to get better performance (King, 2009). Absorptive capacity helps to enhance the information system of the organization. In this context, Mustafa and Flanagan (2012) mentioned that the assimilation capability of absorptive capacity indicates the capability of the organization's process, analyze, explanation, and understanding the information. On the bases of this discussion we argued that:

$H_{1}$. Absorptive capacity is positively related to the organization's innovation performance.

\subsection{Absorptive capacity and dominant logic}

Some researchers mention that due to dominant logic there is some shared cognitive schema among top managers that are important to manage large firms. Furthermore they mentioned that among top managers dominant logic is a "missing link" between diversification and performance. Moreover, they mentioned that without dominant logic firms cannot get high performance (Charles, 2000). On natureversus-nature database it is argued that, firms are not only dependent on external environment, but also on managers' history as well as their path-dependent choices (Child, 1972; Penrose, 1959; Porter, 1991). The resource-based view (RBV) states that competitive advantage starts inside the organization and takes the form of valuable, difficult to emulate, rare, and diverse resource that builds over time in path-dependent ways (Barney, 1986a; Barney, 1986b; Barney, 1991; Peteraf, 1993; Wernerfelt, 1984; Dierieckx, 1989). It was argued that such resources are beneficial to raise superior performance (Hoopes, 2003; Lippman, 2003; Schoemaker, 1990). Teece (2000) mentioned that at different situations there are different knowledge requirements depending on the cost and demand at work, appropriate administration in which organization performs its functions, compatibility principles, characteristics of innovation, and the prosperity of the technical opportunity facing the organization. Furthermore, they mentioned that managerial challenges that are based on the centrality of information and intellectual property are far more diverse from physical assets that involve gaining competitive advantage. Combining information technology (IT) and co-aligned organizational practices can improve the ability of 
learning and competitive advantage. Moreover, understanding knowledge can help in knowledge transfer and sharing also helps organizations become innovative and creative. Once the knowledge is clear, it is easier to store, transfer, and share. On the other hand once the data is codified it is harder to protect, it can leak out and can get into the wrong hands quickly. However, strong intellectual property protects this information (Teece, 2000). Meyer (1979) mentioned that public organizations continuously change; due to frequent changes in political environment it is difficult to implement and maintain longterm changes in the public sector organizations. Fernandez (2007) mentioned that some of the recent studies show that a change in top-level management can be effective for organizational change. Boeker (1997) discussed the top managers across organizations and their influence over the organization's decision making process to enter into new markets. The new executives can promote changes in organizations by promoting knowledge transfer, organizational learning, new cognitive models and assumptions, and the displacement of present organizational values (Fernandez, 2007). Simon (1995) mentioned that managers are rationally bounded, they have to depend on simplified world representations to process information. These insufficient representations start from the basis of mental development model and strategic beliefs that constrain managerial decisions. Managerial cognitive capabilities are dependent on the basis of past experience as contrast to current knowledge, that is available in the environment (Kiesler, 1982). For example, over time as managers work together they build up a set of beliefs for the organization that are based on their past experience. In the reference of historical environment regarding development of beliefs, top managers repeatedly have difficulty while changing environment, adapting mental models that also have negative influence over organizational performance (TRIPSAS, 2000). From the above we argue that:

$H_{2}$. Absorptive capacity has a positive influence over dominant logic.

\subsection{Dominant logic and innovation performance}

Numerous public management studies show that managerial leadership has significant influence on organizational change (Fernandez, 2007). For example, the study of Hennessey (1998) shows the impact of top management on the outcome of public sector organizations. Furthermore, the author mentions the effect of leadership on changes in culture, organizational climate as envisioned by the reinventers, by these changes superior organizational performance can be achieved. Through dynamic capabilities of managers alter their resource base acquire an important resource, combine them together, and recombine them (Eisenhardt, 2000). They integrate sets of particular, identified processes that are commonly accepted as "best practices" which might examine, compare and sometimes transfer from one organization to another organization. This dynamic capability activates and maintains inter-firm performance (Henderson, 1994). Latest theoretical studies focus on the development of managerial decisions as well as flexible strategic choices as important factors in the development of capabilities (Helfat, 2003; Zahra, 2002). Connections concerning strategies and performance have received a huge interest from researchers and produced regular set of findings (Branzei, 2006). Depending on the characteristics of environment and organization (Covin, 1990; Covin \& Slevin, 1990; McDougall, 1992; Kelley, 2002), tremendous focus on the strategic choices (Sandberg, 1986), also over time better constancy of these choices. Freeser and Willard (1990) developed survival chances of firms McCann (1991), developed new venture growth, furthermore active advance market as well as financial performance (Schroeder, 2002). Some of these studies describe the relationship of strategies and performance that depend on the resource-based capabilities (Chandler \& Hanks, 1994), and fit between firms' strategies and their existing capabilities (Fingenbaum \& Karnani, 1991). The above discussion shows that top management is key factor for firms' performance and that their dynamic capabilities have positive effect on the development of the firms' performance. From the discussion above we develop the following hypothesis:

$H_{3}$. Dominant logic is positively related to the organizations' innovation performance. 


\section{Methodology}

For this study we collect data from public sector organizations located in Hefei (Anhui province) of China. Different levels of employees were questioned using survey questionnaire that was adopted from Zahra (2002), Obloj (2010), and Alegre and Chiva (2013). We translated the questionnaire into Chinese for the convenience of the target sample (Leung, 2009). In order to have a certainty that the meaning of the translated questionnaire did not change we translated it back into English to verify and concluded that the items had the same meaning.

\subsection{Dependent variable}

\subsubsection{Innovation Performance}

The ability of organizational learning is related to innovation. Calantone et al. (2002) and Alegre et al. (2008) mentioned that organizational learning is the fact that precedes the innovation. Jiménez-Jiménez and Sanz-Valle (2011) mentioned that innovation, organizational learning and performance are interconnected factors. Innovation may affect directly the organizational performance or work with the innovative performance and increase organizational overall innovativeness (Alegre, 2006). Innovation is the most important element of today's knowledge-based economy in the world for gaining competitive advantage under rapidly changing environment (Chen, 2009). Innovation is a core element of strategy and performance studies along with knowledge and capabilities (Zehir, 2016). We used seven point Likert scale in this study to measure innovation performance from strongly disagree $=1$ to strongly agree $=7$.

\subsection{Independent variable}

\subsubsection{Absorptive capacity}

Cohen and Levinthal (1989) mentioned that ACAP is the ability of learning from environment by multiple processes, for instance, attainment, absorption and exploitation. Cohen (1990) redefined ACAP Construct as the capability of organization to value, absorb and routine knowledge that is absorbed from external sources. According to this new approach ACAP is considered as a by-product not only for activities of R\&D, but also of the breath of the organization's knowledge base, learning experience, collective language, the existence of cross- functional interfaces plus problem solving and mental models, capability of the organizations' members. In this study to measure the dimensions of ACAP we used seven Likert scale from strongly disagree $=1$ to strongly agree $=7$.

\subsubsection{Dominant Logic}

As mentioned earlier that dominant logic is the DNA of the organization (Prahalad, 2004, p. 172) without dominant logic it is impossible to manage the tangible and intangible resources of the organizations. Moreover, DL deals with the resource allocation and making important decisions (Prahalad, 2004, p. 172) that may affect the firms' performance. In emerging economies, dominant logic plays an important role, where limited resources are available in the environment (Amit \& Schoemaker, 1993; Barney, 1991). To measure the dimensions of dominant logic we used seven point Likert scale from strongly disagree $=1$ to strongly agree $=7$.

\section{Results and Discussion}

Table 1 shows the mean, standard deviation and correlations between variables. Table 1 describes that absorptive capacity is positively and significantly related to dominant logic $(\mathrm{r}=.541, \mathrm{p}=.001)$, and 
positively related to innovation performance $(\mathrm{r}=.716, \mathrm{p}=.001)$. In addition, dominant logic is positively and significantly related to innovation performance $(r=.735, p=.001)$. These results show that absorptive capacity and dominant logic are the important predictors of innovation performance.

Furthermore, regression analysis is performed to check the strength of relationship among variables. A significant relationship was found to check the relationship between ACAP, DL and IP (F $(2,292)=$ $308.85, \mathrm{p}=.000$ ), with $\mathrm{R}^{2}$ of .679 . These results prove hypotheses 1,2 and 3 in which absorptive capacity has positive relationship with dominant logic and innovation performance, and dominant logic has positive relationship with innovation performance.

\section{Table 1}

Mean, Std. Deviation and correlation between absorptive capacity, dominant logic and innovation performance

\begin{tabular}{lccccc}
\hline Variables & Mean & Std. Deviation & ACAP & DL & IP \\
\hline ACAP & 4.9716 & 1.23266 & 1 & & \\
DL & 4.8359 & .74066 & $.541^{* *}$ & 1 & 1 \\
IP & 4.8626 & 1.04239 & $.716^{* *}$ & $.735^{* *}$ & 1 \\
\hline
\end{tabular}

Table 2

Model summary of the ACAP, DL and IP

\begin{tabular}{|c|c|c|c|c|c|c|c|c|c|}
\hline \multirow[b]{2}{*}{ Model } & \multirow[b]{2}{*}{$\mathrm{R}$} & \multirow[b]{2}{*}{ R Square } & \multirow[b]{2}{*}{ Adjusted R Square } & \multirow[b]{2}{*}{$\begin{array}{l}\text { Std. Error of the } \\
\text { Estimate }\end{array}$} & \multicolumn{5}{|c|}{ Change Statistics } \\
\hline & & & & & R Square Change & F Change & $\mathrm{df1}$ & $\mathrm{df} 2$ & $\begin{array}{c}\text { Sig. F } \\
\text { Change }\end{array}$ \\
\hline 1 & $.734^{\mathrm{a}}$ & .539 & .537 & .74359 & .539 & 342.220 & 1 & 293 & .000 \\
\hline 2 & $.824^{\mathrm{b}}$ & .679 & .677 & .62136 & .140 & 127.605 & 1 & 292 & .000 \\
\hline
\end{tabular}

Table 3

Regression analysis between ACAP, DL and IP

\begin{tabular}{llrrrrr}
\hline Model & & Sum of Squares & df & Mean Square & F & Sig. \\
\hline 1 & Regression & 238.489 & 2 & 119.244 & 308.850 & $.000^{\text {c }}$ \\
\cline { 2 - 6 } & Residual & 112.739 & 292 & .386 & & \\
\cline { 2 - 6 } & Total & 351.228 & 294 & & & \\
\hline a. Dependent Variable: IP1 & & & & & \\
b. Predictors: (Constant), DL1 & & & &
\end{tabular}

Table 4

Coefficients of ACAP, DL and IP

\begin{tabular}{llccccc} 
Model & \multicolumn{9}{c}{$\begin{array}{c}\text { Standardized } \\
\text { Coefficients } \\
\text { Bnstandardized Coefficients } \\
\text { B }\end{array}$} & Std. Error & Beta & Sig. \\
\hline 1 & (Constant) & -.367 & .240 & & -1.526 & .128 \\
& & .726 & .058 & .491 & 12.440 & .000 \\
& DL & .396 & .035 & .446 & 11.296 & .000 \\
\hline
\end{tabular}

a. Dependent Variable: IP1 


\section{Conclusion}

One key aspect in which the public sector organizations need to be more focused on creativity and innovation is the fact that the private enterprises have been rigorously innovating in terms of products and systems, whereas the public sector or rather the government organizations have not been developing at the same pace as their counterparts. This makes it difficult for organizations to survive in such a dynamic fast paced market place. The relationship proven in this study further attests to the fact that innovation without knowledge and leadership is impossible. The focus in this study was on leadership and knowledge, and their impacts on innovation performance. In the past literature absorptive capacity, dominant logic and innovation performance were discussed in different organizations and separately. This study combined these variables to check the public organizations performance. We have found a positive relationship among these variables which have indicated that without leadership and knowledge it is impossible for public organizations to improve their performance. This paper has also provided an insight regarding knowledge absorption for top management in public sector organizations and how the top management could use their dynamic capabilities to improve performance and foster an innovative environment.

\section{References}

Alegre, J., Lapiedra, R., \& Chiva, R. . (2006). A measurement scale for product innovation performance. European Journal of Innovation Management, 9(4), 333-346.

Alegre, J., \& Chiva, R. (2013). Linking entrepreneurial orientation and firm performance: the role of organizational learning capability and innovation performance. Journal of Small Business Management, 51(4), 491-507.

Amit, S. (2003). Unraveling the Resource-Based Tangle. Managerial and Decision Economics, 24 (2), 309-323.

Amit, R. (1993). Strategic Assets and Organizational Rent. Strategic Management Journal, 14, 33-46.

Barney, J. (1986a). Strategic factor markets: expectations, luck and business strategy. Management Science, 323, 1231-1241.

Barney, J. (1986b). Organization culture: can it be a source of sustained competitive advantage? . Academy of Management Review, 11, 656-665.

Barney, J. (1991). Firm resources and sustained competitive advantage. Journal of Management, 17(1), 99-100.

Boeker, W. (1997). Executive migration and strategic change: The effect of top management movement on product market entry. Administrative Science Quarterly, 42, 213-236.

Branzei, O. (2006). Strategic pathways to product innovation capabilities in SMEs. Journal of Business Venturing, $2175-105$.

Bruton, G. D. (2008). Entrepreneurship in Emerging Economies: Where Are We Today and Where Should the Research Go in the Future. ET\&P, 1042-2587.

Calantone, R. J., Cavusgil, S. T., \& Zhao, Y. (2002). Learning orientation, firm innovation capability, and firm performance. Industrial Marketing Management,, 31(6), 515-326.

Carmeli, A. a. T., A. (2004). The relationships between intangible organizational elements and organizational performance. Strategic Management Journal, 25 (13), 1257- 1278.

César Camisón, B. F. s. (2010). Knowledge absorptive capacity: New insights for its conceptualization and measurement. Journal of Business Research, 63, 707-715.

Chandler, G. N., Hanks, S.H. (1994). Market attractiveness, resource-based capabilities, venture strategies, and venture performance. Journal of Business Venturing, 9(4), 331-349.

Charles, H. (2000). Dominant logic and the iron cage. Advances in Strategic Management, 17, $187-$ 191.

Chen, C.-L., and Jaw, Y.-L. . (2009). Building global dynamic capabilities through innovation: A case study of Taiwan's cultural organizations. Journal of Engineering and Technology Management, 26 (4), 247-263. 
Child, J. (1972). Organizational structure, environment and performance: the role of strategic choice. Sociology, 6, 1-22.

Cohen, W. M., \& Levinthal, D. A. (1989). Innovation and learning: the two faces of R \& D. The economic journal, 99(397), 569-596.

Cohen, L. (1990). Absorptive Capacity: A New Perspective on Learning and Innovation. JSTOR, 128152.

Covin, J. G., Slevin, D.P. (1990). New venture strategic posture, structure, and performance: an industry life cycle analysis. Journal of Business Venturing, 5(2), 123-135.

Covin, J. G., Slevin, D.P., \& Covin, T.J. (1990). Content and performance of growth-seeking strategies: a comparison of small firms in high- and low-technology industrie. Journal of Business Venturing, 5 (6), 391-412.

Davenport, T. H. P., L. (1998). Working Knowledge: How Organizations Manage What They Know. Harvard Business School Press. Boston.

Dierickx, c. (1989). Asset stock accumulation and sustainability of competitive advantage. Management Science, 35(12), 1504-1511.

Eisenhardt, K., and J. Martin. (2000). Dynamic capabilities: what are they? Strategic Management Journal, 21, 11051121.

Ellis, H. C. (1965). The Transfer of Learning. New York: MacMill.

Estes, W. K. (1970). Learning Theory and Mental Development. New York. Academic Press.

Fernandez. (2007). Under what conditions do public managers favor and pursue organizational change? The American Review of Public Administration, 37, 324-341.

Fingenbaum, A., \& Karnani, A. (1991). Output flexibility: a competitive advantage for small firms. Strategic Management Journal, 12(2), 101-114.

Freeser, H., Willard, G. (1990). Founding strategy and performance: a comparison of high and low growth high-tech firms. Strategic Management Journal, 11, 367-386.

Grundstein, M. (2007). Knowledge workers as an integral component in global information system design,. Information Resources Management. Global Challenge, Idea Group Publishing, 236-261.

Gupta, A. K., \& Govindarajan, V. (2000). Knowledge management's social dimension: Lessons from Nucor Steel. MIT Sloan Management Review, 42(1), 71.

Helfat, C. E., Peteraf, M.A. (2003). The dynamic resource-based view: capability life cycles. Strategic Management Journal, 24, 997-1010.

Henderson, R., Cockburn. (1994). Measuring competence: exploring firm effects in pharmaceutical research. Strategic Management Journal, 15, 63-84.

Hennessey, J. T. (1998). "Reinventing" government: Does leadership make a difference? Public Administration Review, 58, 322-332.

Ho, L.-A. (2008). What affects organizational performance?: The linking of learning and knowledge management. Industrial Management and Data Systems, 108 (9), 1234-1254.

Hogarth, R. M. (2001). Educating intuition. Chicago. University of Chicago Press.

Hoopes, D. G., Tammy Madsen \& Gordon Walker. (2003). Why is there a resource-based view? towards a theory of competitive heterogeneity. Strategic Management Journal, 24, 889-902.

Huff, A. S. (1982). Industry influences on strategy reformulation. Strategic Management Journal, 3(2), 119-131.

Jiménez-Jiménez, D., \& Sanz-Valle, R. (2011). Innovation, organizational learning, and performance. Journal of Business Research, 64(4), 408-417.

Kelley, D. J., \& Rice, M.P. (2002). Advantage beyond founding: the strategic use of technologies. Journal of Business Venturing, 17, 41-57.

Kiesler S, S. L. (1982). Managerial response to changing environments: perspectives on problem sensing from social cognition. Administrative Science Quarterly, 27, 548-570.

King, W. R. (2009). Knowledge management and organizational learning. Annals of information systems. Springer Science., 4. doi:10.1007/978-1-4419-0011-1_1 
Leung, S. F. (2009). Psychometric properties of the SCOFF questionnaire (Chinese version) for screening eating disorders in Hong Kong secondary school students: A cross-sectional study. International Journal of Nursing Studies, 46, 239-247.

Lin, C., Tan, B., \& Chang, S. (2002). The critical factors for technology absorptive capacity. Industrial Management \& Data Systems, 102(6), 300-308.

Lippman, S., A. \& Richard Rumelt. (2003). The payments perspective: micro-foundations of resource analysis. Strategic Management Journal, 24, 903-927.

Makadok, R. (2001). Toward a synthesis of the resource-based and dynamic-capability views of rent creation. Strategic Management Journal, 22(5), 387-401.

McCann, J. E. (1991). Patterns of growth, competitive technology, and financial strategies in young ventures. Journal of Business Venturing, 6 (3), 189-208.

McDougall, P. P., Robinson Jr., R.B., DeNisi, A.S. (1992). Modeling new venture performance: an analysis of new venture strategy, industry structure, and venture origi. Journal Business Venturing, 7, 276-289.

Meyer, M. W. (1979). Organizational structure as signaling. Pacific Sociological Review, 22(4), 481500 .

Meyer, K. E., \& Peng, M. W. (2005). Probing theoretically into Central and Eastern Europe: Transactions, resources, and institutions. Journal of International Business Studies, 36(6), 600-621.

Mustafa Kamal, E., \& Flanagan, R. (2012). Understanding absorptive capacity in Malaysian small and medium sized (SME) construction companies. Journal of Engineering, Design and Technology, 10(2), 180-198.

Nadkarni. (2007). Prior conditions and early international commitment: the mediating role of domestic mindset. Journal of International Business Studies, 38, 160-176.

Newbert, S. L. (2007). Empirical research on the resource-based view of the firm: An assessment and suggestions for future research. Strategic Management Journal, 28(2), 121-146.

Kolvereid, L., \& Obloj, K. (1994). Entrepreneurship in Emerging Versus Mature Econom ies: An Exploratory Survey. International Small Business Journal, 12(4), 14-27.

Oblój, K., \& Pratt, M. (2005). Happy kids and mature losers: Differentiating the dominant logics of successful and unsuccessful firms in emerging markets. Strategy in transition, 81-104.

Obloj, T. (2010). Dominant Logic and Entrepreneurial Firms' Performance in a Transition Economy. ET\&P, 1042-2587.

Penrose, E. (1959). The theory of the growth of the firm. Oxford University Press, Oxford.

Peteraf, M. A. (1993). The cornerstones of competitive advantage: a resource based view. Strategic Management Journal, 14 (3), 179-191.

Pirolli, P. L., \& Anderson, J.R. (1985). The role of learning from ex- ample in the acquisition of recursive programming skill. Canadian Journal of Psychology, 39, 240-272.

Porter, M. (1991). Towards a dynamic theory of strategy. Strategic Management Journal, 12, 95-117.

Prahalad, C. K., \& Bettis, R. A. (1986). The dominant logic: A new linkage between diversity and performance. Strategic management journal, 7(6), 485-501.

Prahald. (2004). The blinders of dominant logic. Long Range Planning, 37, 171-179.

Sandberg, W. R. (1986). New Venture Performance: The Role of Strategy and Industry Structure. Lexington, Lexington, MA.

Schoemaker, P. (1990). Strategy, complexity, and economic rent. Management Science, 36(10), 11781192.

Schroeder, R. G., Bates, K.A., \& Junttila, M.A. (2002). A resource-based view of manufacturing strategy and the relationship to manufacturing performance. Strategic Management Journal, 23, 105-117.

Siggelkow, N. (2002). Misperceiving interactions among complements and substitutes: Organizational consequences. Management Science, 48(7), 900-916.

Simon, H. A. (1995). A behavioral model of rational choice. Quarterly Journal of Economics, 69, 99118. 
Szulanski, G. (2000). The process of knowledge transfer: A diachronic analysis of stickiness. Organizational Behavior and Human Decision Processes, 82(1), 9-27.

Teece, D. J., Pisano, G., \& Shuen, A. (1997). Dynamic capabilities and strategic management. Strategic Management Journal, 18(7), 509-533.

Teece, D. J. (2000). Strategies for managing knowledge assets: The role of firm structure and industrial context. Long Range Planning, 33, 35-54.

TRIPSAS, M. (2000). Capabilities, cognition and inertia: Evidence from digital imaging. Strategic Managemeny Journal, 21, 1147-1161.

Wernerfelt, B. (1984). A resource-based view of the firm. Strategic Management Journal, 5, 171-180.

Wiig, K. M. (2003). Knowledge Management Foundations. Schema Press. Arlington.

Zahra. (2002). Absorptive capacity: A review, reconceptualization, and extension Academy of management review, 27, 185-203.

Zehir, C. (2016). The effect of SHRM practices on innovation performance: The mediating role of global capabilities. Procedia - Social and Behavioral Sciences, 235797 - 806.

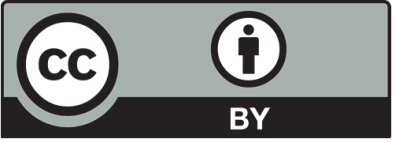

(C) 2017 by the authors; licensee Growing Science, Canada. This is an open access article distributed under the terms and conditions of the Creative Commons Attribution (CC-BY) license (http://creativecommons.org/licenses/by/4.0/). 